\title{
Effects of the probiotic Bacillus amyloliquefaciens on growth performance, hematology and intestinal morphometry in cage-reared Nile tilapia
}

\author{
Thiago Fernandes A. Silva ${ }^{1}$, Thalita R. Petrillo ${ }^{2}$, Jefferson Yunis-Aguinaga ${ }^{1}$, Paulo Fernandes \\ Marcusso $^{2}$, Gustavo da Silva Claudiano ${ }^{2}$, Flávio Ruas de Moraes ${ }^{2}$ \& Julieta R. Engrácia de Moraes ${ }^{1,2}$ \\ ${ }^{1}$ Aquaculture Center of Unesp, São Paulo State University (Unesp), Jaboticabal, Brazil \\ Via Prof. Paulo Donato Castellane, km 05, Jaboticabal, SP. 14.884-900 \\ ${ }^{2}$ Department of Veterinary Pathology, São Paulo State University (Unesp), Jaboticabal, Brazil \\ Corresponding author: Julieta Engrácia de Moraes（julietaengracia@gmail.com)
}

\begin{abstract}
The aim of this study was to evaluate the effect of probiotic Bacillus amyloliquefaciens on the growth performance, blood profile and intestinal morphometry in Nile tilapia (Oreochromis niloticus) reared in cages. 936 Nile tilapias were distributed in 12 cages $\left(1.5 \mathrm{~m}^{3}\right)$. Fish were fed for 90 days on basal diets containing 0 (control); $1 \times 10^{6} \mathrm{CFU} \mathrm{g}^{-1} ; 5 \times 10^{6} \mathrm{CFU} \mathrm{g}^{-1}$; and $1 \times 10^{7} \mathrm{CFU} \mathrm{g}{ }^{-1}$ of the probiotic. The results showed no significant difference on performance and proximal composition of fish. Blood glucose and hemoglobin were lower in $1 \times 10^{7} \mathrm{CFU} \mathrm{g}{ }^{-1}$ group, suggesting improves of the homeostatic state of the fish. Other hematimetric indices did not differ between groups. It was observed significant increase of villi height and in the number of goblet cells of the intestine in fish supplemented $5 \times 10^{6} \mathrm{CFU} \mathrm{g}{ }^{-1}$ and $1 \times 10^{7} \mathrm{CFU} \mathrm{g}{ }^{-1}$ of food suggesting that fish improved the digestion and absorption of nutrients. However, more studies are needed to determine the efficacy of this probiotic in field conditions in Nile tilapia.
\end{abstract}

Keywords: Oreochromis niloticus, homeostatic state, intestinal morphology, blood glucose, aquaculture.

\section{Efectos del probiótico Bacillus amyloliquefaciens en el crecimiento, hematología y morfometría intestinal en tilapias del Nilo criadas en balsa jaula}

\begin{abstract}
RESUMEN. El objetivo de este estudio fue evaluar el efecto del probiótico Bacillus amyloliquefaciens en el desempeño del crecimiento, hemograma y morfometría intestinal en tilapia del Nilo (Oreochromis niloticus) criadas en balsas jaulas. 936 tilapias del Nilo se distribuyeron en 12 balsas jaulas $\left(1,5 \mathrm{~m}^{3}\right)$. Los peces fueron alimentados durante 90 días con dietas que contenían 0 (control); $1 \times 10^{6} \mathrm{UFC} \mathrm{g}^{-1} ; 5 \times 10^{6} \mathrm{UFC} \mathrm{g}^{-1}$ y $1 \times 10^{7}$ UFC $\mathrm{g}^{-1}$ del probiótico. Los resultados no mostraron diferencias significativas en el rendimiento y composición proximal de los peces. La glucosa en sangre y hemoglobina fue menor en el grupo $1 \times 10^{7} \mathrm{UFC}^{-1}$, lo que sugiere un mejor estado homeostático de los peces. Otros parámetros hematimétricos no difirieron entre los grupos. Se observó aumento significativo de la altura de las vellosidades y número de células caliciformes del intestino en los peces suplementados con $5 \times 10^{6} \mathrm{UFC} \mathrm{g}^{-1}$ y $1 \times 10^{7} \mathrm{UFC} \mathrm{g}^{-1}$ de alimento que sugieren que los peces mejoraron la digestión y absorción de nutrientes. Sin embargo, se necesitan más estudios para determinar la eficacia de este probiótico en condiciones de campo en tilapia del Nilo.
\end{abstract}

Palabras clave: Oreochromis niloticus, homeostasis, morfología intestinal, glucosa sanguínea, acuicultura.

\section{INTRODUCTION}

Nile tilapia reared in cages presents advantages over traditional pond and tank systems due to the easier handling, high volume of production, and use of areas unsuitable for other purposes, and the biological characteristics of this species (García et al., 2014). Al- though the productivity advantages (Kim et al., 2014), fish at high stocking densities may present stress and depress the immune system, increasing susceptibility to bacterial and parasitic diseases (Telli et al., 2014).

The use of antibiotics as prophylactic is questioned for being a source of environmental pollution (Ayandiran et al., 2014), accumulating in the fillet, and promoting

Corresponding editor: Mauricio Laterça 
resistance to drugs with risks to human and animal health (Kersarcodi-Watson et al., 2008).

Probiotics are live microorganisms able to establish, multiply and colonize the intestine of the host in order to promote a beneficial balance of microorganisms. These benefits are explain due to these microorganisms inhibit the proliferation of harmful agents in the intestinal mucosa, improve the digestibility and absorption of nutrients (Nayak, 2010), promote the synthesis of vitamins (Lee et al., 2013), and improve the growth performance of animals (Mohapatra et al., 2014 ) by increasing the survival percentage (Wu et al., 2014) and water quality (Chi et al., 2014).

Bacteria from genus Bacillus are one of the main probiotics used in aquaculture. These bacteria are ease to cultivate and form spores, which facilitates its conservation (Wang et al., 2008; Nayak, 2010; Han et $a l ., 2015)$. In addition, several bacteria of this genus have the capacity to secrete antimicrobial compounds and different exoenzymes that aid digestion (ZiaeiNejad et al., 2006).

Bacillus amyloliquefaciens (ex Fukomoto, 1943) Priest et al., 1987 is a non-pathogenic bacterium rodshaped, aerobic, Gram-positive, and catalase positive (Loncar et al., 2014). This bacterium is highly resistant to environmental changes (Mahdhi et al., 2012; Das et al., 2013), presents antibacterial activity of broad spectrum (Kaewklom et al., 2013), and is an important producer of $\alpha$-amylase, an enzyme that acts in the digestion of carbohydrates (Wang et al., 2008).

Recently, in studies with B. amyloliquefaciens Reda \& Selim (2015) observed in O. niloticus reared in laboratory conditions; improve in body composition and intestinal morphology. Ridha \& Azad (2012) reported in the same fish improvements on growth performance and immune response. Cao et al. (2011) observed in Anguilla anguilla, antagonist activity of $B$. amyloliquefaciens and Aeromonas hydrophila. The same effect was observed by Ran et al. (2012) in Ictalurus punctatus against $A$. hydrophila and Edwardsiella ictaluri. Das et al. (2013) observed an increase in disease resistance in Catla catla.

The aim of this study was to evaluate the effect of diet containing three concentrations of the probiotic $B$. amyloliquefaciens on performance, blood profile and intestinal morphology in Nile tilapia, O. niloticus, reared in cages.

\section{MATERIALS AND METHODS}

\section{Fish culture, diet and feeding}

Masculinized Nile tilapia (Oreochromis niloticus) (35 $\pm 5 \mathrm{~g}$ ) from the same spawning were obtained from commercial breeding. The cages $\left(1.5 \mathrm{~m}^{3}\right)$ were distri- buted in four experimental groups (triplicate) in a completely randomized design (78 fish per cage). The experiment was conducted in the reservoir 3 of the Aquaculture Center of Sao Paulo State University, Jaboticabal $\left(21^{\circ} 14.33^{\prime} \mathrm{S}, 48^{\circ} 17.55^{\prime} \mathrm{W}\right)$ in April-June 2014. This reservoir has approximately 10,000 surface $\mathrm{m}^{2}$.

The animals were acclimated for 10 days and fed with basal diet (pellets used in this experiment without addition of probiotics). It was used the program "Super Crac Premium" to formulate the diet according the suggestions of Furuya (2010). Feed was extruded. The feed rate was $3 \%$ of body weight, 3 times a day for 90 days on basal diets containing 0 (control); $1 \times 10^{6} \mathrm{CFU}$ $\mathrm{g}^{-1} ; 5 \times 10^{6} \mathrm{CFU} \mathrm{g}{ }^{-1}$; and $1 \times 10^{7} \mathrm{CFU} \mathrm{g} \mathrm{g}^{-1}$ of Bacillus amyloliquefaciens.

Diet composition is shown in Table 1. To achieve homogeneous final concentrations of bacteria in the diet and to facilitate the adhesion of the probiotic, the bacterial suspension was added and homogenized manually with commercial vegetable oil $(4 \%$ by weight; $4.000 \mathrm{kcal} \mathrm{L}^{-1}$ ). Thus, according to the recommendations of Das et al. (2013) food was prepared every 7 days to maintain optimal probiotic levels.

Fish were measured at 30 and 60 days for diet amount adjustment. During the experimental period, except temperature, there were no important changes in the water quality that could have interfered in the experiment results (Boyd \& Massaut, 1999). The values were maintained as follows: the water temperature varied from 27.1 to $21.9^{\circ} \mathrm{C}\left(24.35 \pm 2.43^{\circ} \mathrm{C}\right)$ and dissolved oxygen $\left(7.31 \pm 0.48 \mathrm{mg} \mathrm{L}^{-1}\right)$. Both were measured using an YSI 53 device (YSI Company, USA); $\mathrm{pH}(7.50 \pm 0.30)$ and electrical conductivity $(45.54 \pm 10.40 \mu \mathrm{V})$ were measured using a 63 YSI device (YSI Company, USA). Water transparency $(26.03 \pm 2.10 \mathrm{~cm})$ was measured using the Secchi disk at 11:00 $\mathrm{h}$ on alternate days.

\section{Isolation and identification of the probiotic bacterial strain}

The bacterium was isolated from a commercial product containing Bacillus amyloliquefaciens. To confirm the presence of the bacteria in the product, $1.0 \mathrm{~g}$ of the probiotic was homogenized in $99 \mathrm{~mL}$ of phosphate buffered saline $\left(145 \mathrm{mM} \mathrm{NaCl}, 1.4 \mathrm{mM} \mathrm{NaH}_{2} \mathrm{PO}_{4}, 8\right.$ $\mathrm{mM} \mathrm{Na} 2 \mathrm{HPO}_{4}, \mathrm{pH}$ 7.4). Thus, it was performed serial dilutions with peptone solution (4\%) (Sigma-Aldrich, USA), distributed into Petri dishes containing culture medium trypticase soy Agar (TSA), and incubated for $48 \mathrm{~h}$ under aerobic conditions at $26^{\circ} \mathrm{C}$. Colonies of Bacillus sp. were identified according their morphological, biochemical and dyeing features (Priest et al., 
Table 1. Ingredients and proximal composition of the basal diet.

\begin{tabular}{lr}
\hline Ingredients & \multicolumn{1}{c}{$\%$} \\
\hline Corn flour & 30.000 \\
Soybean meal $(38 \% \mathrm{CP})$ & 20.000 \\
Rice bran & 14.766 \\
Wheat flour & 13.000 \\
Corn gluten $(20 \% \mathrm{CP})$ & 12.000 \\
Poultry by-product meal (65\% CP) & 5.000 \\
Fish meal (60\% CP) & 3.000 \\
DL-Methionine & 0.700 \\
Dicalcium phosphate & 0.610 \\
L-Tryptophan & 0.200 \\
L-Lysine & 0.164 \\
Antifungi & 0.030 \\
Antioxidant & 0.030 \\
Vitamin mix & \\
Proximal composition $(\%)$ & 0.500 \\
Dry matter & \\
Crude protein & 90.10 \\
Digestible energy (kcal kg $\left.{ }^{-1}\right)$ & 30.21 \\
Ether extract & 2990.12 \\
Fiber & 4.98 \\
Ash & 4.67 \\
\hline
\end{tabular}

${ }^{1}$ Composition of vitamin-mineral supplement (Fri-Ribe): vitamin A, 600,000 IU; Vitamin D3 600,000 IU; Vitamin E 12,000 IU; Vitamin K3, 1200 mg; vitamin B1, 1200 $\mathrm{mg}$; vitamin B2, $1536 \mathrm{mg}$; vitamin B6, $1287 \mathrm{mg}$; B12, $4000 \mathrm{mg}$; folic acid, $198 \mathrm{mg}$; pantothenic acid, $3800 \mathrm{mg}$; Vitamin C, 48,000 mg; biotin, $20 \mathrm{mg}$; choline, 30,000 mg; niacin 19,800 mg; Fe, 25,714 mg; $\mathrm{Cu}, 1960 \mathrm{mg}$; $\mathrm{Mn}$, 13,334 mg; Zn, 6000 mg; I, 948 mg; Co, 2 mg; Se, 30.10 mg.

1987). The sequencing of $16 \mathrm{~S}$ rDNA gene was performed from isolated colonies by the method of Sanger et al. (1977).

The quantification of the probiotic bacteria in the feed was performed by homogenizing $1.0 \mathrm{~g}$ of diet in $99 \mathrm{~mL}$ of PBS. Then, it was performed serial dilutions as described above. Finally, they were evaluated the colonies that showed morphological, biochemical, and dyeing features compatible with B. amyloliquefaciens. Samples of all treatments were subjected to molecular identification of the bacterium as described previously.

\section{Growth performance}

After 90 days, fish were measured and weighed to determinate performance indices:

- Weight gain $(\mathrm{WG})=$ Final weight - initial weight

- Specific growth rate $(\mathrm{SGR})=(\operatorname{In}[$ final weight] In[initial weight]) x 100/number of days
- Feed efficiency $(\mathrm{FE})=$ weight gain $\mathrm{x}$ 100/food consumed

\section{Proximal composition}

After the feeding period, 10 fish from each group were euthanized using benzocaine $\left(0.5 \mathrm{~g} \mathrm{~L}^{-1}\right)$ (Wedemeyer, 1970) and stored at $-18^{\circ} \mathrm{C}$ for later analysis of proximal composition. Then the samples were ground to obtain a homogenous product and dried in an oven at $55^{\circ} \mathrm{C}$ for $48 \mathrm{~h}$. The humidity was determined by drying in an oven at $105^{\circ} \mathrm{C}$ for $24 \mathrm{~h}$. The ash content was obtained after incineration in a muffle furnace at $550^{\circ} \mathrm{C}$ and the energy by bomb calorimetry. Protein was determined by Kjeldahl method and the ether extract by Soxhlet method (AOAC, 2005).

\section{Hematological profile and glucose}

After anesthesia, blood of 10 fish per replicate were collected by puncture of the caudal vessel and distributed in tubes containing EDTA (10\%) for determination of hematocrit (Goldenfarb et al., 1971), hemoglobin (Collier, 1944) and, red blood cell counts using the solution Natt \& Herrick as diluent and dye. Then, they were calculated the mean corpuscular volume (MCV), mean corpuscular hemoglobin $(\mathrm{MCH})$ and, mean corpuscular hemoglobin concentration (MCHC).

Blood smears were stained with Panotic dye (Laborclin, PR, Brazil) to count leukocytes and thrombocytes. The determination of blood glucose was performed with the rapid glucose analyzer One Touch UltraMini ${ }^{\circledR}$ (Lifescan, CA, USA).

\section{Analysis of intestinal morphometry}

The collection of the intestine was performed in the same fish used in the blood analysis. After deep anesthesia, it was performed a longitudinal incision in the abdomen and collected a fragment of the anterior portion of the intestine located two centimeters after the pylorus. The fragments were fixed in Bouin solution for $24 \mathrm{~h}$. Then, they were dehydrated in $70 \%$ alcohol to histological processing (Honorato et al., 2011). The slides were stained with hematoxylin-eosin (HE) for morphometric evaluation of villi and with periodic acid-Schiff (PAS) for goblet cell count.

The measurement of the height and width of the villi, epithelial thickness, and counting of goblet cells were performed according to Mello et al. (2013). It was used a Zeiss Axio Vision image analyzer.

\section{Statistical analysis}

Data were subjected to analysis of variance (ANOVA), differences between treatments were compared by Tukey 
test $(P<0.05)$. Data were analyzed by statistic $\mathrm{R}$ software (version 0.98.1) and presented as mean \pm standard deviation.

\section{RESULTS}

\section{Performance and proximal composition}

Under the conditions evaluated, there was no statistical difference in weight gain, feed conversion, specific growth rate, and feed efficiency (Table 2). Proximal analysis of fish carcass showed no significant difference between treatment and control groups (Table $3)$.

Hemoglobin and glucose levels showed differences between treatments. The group supplemented with the highest concentration of probiotic $\left(1 \times 10^{7}\right.$ UFC $\left.\mathrm{g}^{-1}\right)$ showed the lower values for these variables. Other red blood cell parameters (Table 4) and differential leukocyte count (Table 5) showed no statistical difference between treatments.

\section{Intestinal morphometry}

Histomorphometric evaluation of the anterior portion of the intestine showed significant difference in the height of the villi in groups supplemented with $5 \times 10^{6}$ $\mathrm{CFU} \mathrm{g}{ }^{-1}$ and $1 \times 10^{7} \mathrm{CFU} \mathrm{g}^{-1}$ compared to $1 \times 10^{6} \mathrm{CFU} \mathrm{g}^{-}$ ${ }^{1}$ and control groups (Fig. 1). There were observed no lesion in the intestine and no differences in the width and thickness of the villi between control and treatment groups (Table 6). Fish that received the highest concentration of probiotic also had significantly greater number of goblet cells comparing to control group (Table 6, Fig. 2).

\section{DISCUSSION}

The use of B. amyloliquefaciens as a probiotic in fish feeding is recent and information is scarce. However, it has demonstrated that dietary supplementation with this bacterium improves growth performance in fish. In tilapia fingerlings reared in glass aquaria, supplementation with this bacterium improved weight gain, specific growth rate and feed conversion after supplement with $10^{6} \mathrm{CFU} \mathrm{g}{ }^{-1}$ of $B$. amyloliquifaciens for 60 days (Reda \& Selim, 2015). However, no differences were observed when the probiotic was administered at $10^{4} \mathrm{CFU} \mathrm{g}^{-1}$ of concentration. Similarly, Telli et al. (2014) found no effect of Bacillus subtilis $\left(5 \times 10^{6} \mathrm{CFU} \mathrm{^{-1 }}\right)$ on performance of Nile tilapia, even after 84 days of feeding supplemented diet.

In this study, there was no effect of the probiotic $B$. amyloliquefaciens on growth performance. This can be explained due to the low temperatures in the last 2 months. Marcusso et al. (2015) reported that the homeostasis of Nile tilapia rearing at temperatures below $24^{\circ} \mathrm{C}$ could be affected, enhancing the susceptibility to bacterial infections and impairing the growth performance.

Ridha \& Azad (2012) tested B. amyloliquefaciens $\left(10^{8} \mathrm{CFU} \mathrm{g}{ }^{-1}\right)$ in Nile tilapia reared in tanks for 99 days and did not find any difference in performance indices either. However, they observed 60 days after that fish

Table 2. Growth performance indices of Nile tilapia fed with experimental diets. WG: weight gain, SGR: specific growth rate, FE: feed efficiency. Mean \pm SD. There were no statistical differences $(P>0.05)$ between treatments.

\begin{tabular}{lccc}
\hline Treatments & WG $(\mathrm{g})$ & SGR $(\%)$ & FE \\
\hline Control & $86.84 \pm 36.53$ & $1.10 \pm 0.51$ & $0.842 \pm 0.245$ \\
$1 \times 10^{6}$ UFC g $^{-1}$ & $83.47 \pm 30.84$ & $1.09 \pm 0.44$ & $0.864 \pm 0.245$ \\
$5 \times 10^{6}$ UFC g $^{-1}$ & $90.44 \pm 39.68$ & $1.13 \pm 0.53$ & $0.791 \pm 0.300$ \\
$1 \times 10^{7}$ UFC g $^{-1}$ & $94.5 \pm 39.66$ & $1.18 \pm 0.55$ & $0.906 \pm 0.206$ \\
\hline
\end{tabular}

Table 3. Body composition (\%) and gross energy $\left(\mathrm{kcal} \mathrm{kg}^{-1}\right)$ of Nile tilapia fed with experimental diets. CP: crude protein, EE: ether extract, M: moisture, Ash; GE: gross energy. Mean \pm SD. There were no statistical differences $(P>0.05)$ between treatments. Values are in \% of dry weight.

\begin{tabular}{lccccc}
\hline Treatments & CP\% & EE \% & M \% & Ash \% & GE $\left(\mathrm{kcal} \mathrm{kg}^{-1}\right)$ \\
\hline Control & $43.1 \pm 0.3$ & $25.8 \pm 0.8$ & $77.5 \pm 0.5$ & $11.8 \pm 0.7^{\mathrm{a}}$ & $5064 \pm 21.1$ \\
$1 \times 10^{6} \mathrm{UFC} \mathrm{g}^{-1}$ & $44.6 \pm 0.4$ & $24.2 \pm 0.9$ & $76.2 \pm 0.3$ & $13.8 \pm 0.4^{\mathrm{a}}$ & $5716 \pm 13.5$ \\
$5 \times 10^{6} \mathrm{UFC} \mathrm{g}^{-1}$ & $39.9 \pm 0.6$ & $25.4 \pm 0.7$ & $76.8 \pm 0.6$ & $12.3 \pm 0.4^{\mathrm{a}}$ & $5150 \pm 16.1$ \\
$1 \times 10^{7} \mathrm{UFCg}^{-1}$ & $42.8 \pm 0.4$ & $26.6 \pm 0.8$ & $77.3 \pm 0.5$ & $12.0 \pm 0.6^{\mathrm{a}}$ & $5635 \pm 18.3$ \\
\hline
\end{tabular}


Table 4. Hematological parameters. Hct: hematocrit, Hb: hemoglobin, RBC: red blood cells, MCHC: mean corpuscular hemoglobin concentration, MCH: mean corpuscular hemoglobin, MCV mean corpuscular volume, and G: plasma glucose of the Nile tilapia fed different probiotic concentrations in feed. Means \pm SD. Values (mean \pm SD) with different letter are significantly different $(P<0.05)$.

\begin{tabular}{lccccccc}
\hline Treatment & $\mathrm{Hct}(\%)$ & $\mathrm{Hb}\left(\mathrm{g} \mathrm{dL}^{-1}\right)$ & $\mathrm{RBC}\left(10^{4} \mu \mathrm{L}^{-1}\right)$ & $\mathrm{MCHC}\left(\mathrm{g} \mathrm{dL}^{-1}\right)$ & $\mathrm{MCH}(\mathrm{pg})$ & $\mathrm{MCV}(\mathrm{fL})$ & $\mathrm{G}\left(\mathrm{mg} \mathrm{dL}^{-1}\right)$ \\
\hline Control & $36.8 \pm 2.9^{\mathrm{a}}$ & $10.75 \pm 1.0^{\mathrm{a}}$ & $295.93 \pm 49.6^{\mathrm{a}}$ & $27.01 \pm 3.4^{\mathrm{a}}$ & $33.05 \pm 5.8^{\mathrm{a}}$ & $125.96 \pm 21.7^{\mathrm{a}}$ & $110.00 \pm 34.9^{\mathrm{a}}$ \\
$1 \times 10^{6} \mathrm{UFC} \mathrm{g}^{-1}$ & $38.5 \pm 3.4^{\mathrm{a}}$ & $11.20 \pm 1.6^{\mathrm{a}}$ & $292.33 \pm 34.6^{\mathrm{a}}$ & $24.44 \pm 3.2^{\mathrm{a}}$ & $32.53 \pm 4.6^{\mathrm{a}}$ & $123.78 \pm 11.0^{\mathrm{a}}$ & $66.80 \pm 36.8^{\mathrm{ab}}$ \\
$5 \times 10^{6} \mathrm{UFC} \mathrm{g}^{-1}$ & $39.2 \pm 1.6^{\mathrm{a}}$ & $10.90 \pm 1.3^{\mathrm{a}}$ & $303.06 \pm 33.4^{\mathrm{a}}$ & $27.95 \pm 4.9^{\mathrm{a}}$ & $35.72 \pm 7.0^{\mathrm{a}}$ & $127.89 \pm 11.8^{\mathrm{a}}$ & $41.40 \pm 9.8^{\mathrm{b}}$ \\
$1 \times 10^{7} \mathrm{UFC} \mathrm{g}^{-1}$ & $37.4 \pm 1.9^{\mathrm{a}}$ & $8.53 \pm 1.2^{\mathrm{b}}$ & $293.50 \pm 36.5^{\mathrm{a}}$ & $26.36 \pm 4.6^{\mathrm{a}}$ & $35.08 \pm 7.9^{\mathrm{a}}$ & $133.31 \pm 20.4^{\mathrm{a}}$ & $36.25 \pm 5.8^{\mathrm{b}}$ \\
\hline
\end{tabular}

Table 5. Differential leukocyte count in the circulating blood of Nile tilapia fed the experimental diets. Means \pm SD. There were no statistical differences $(P>0.05)$ between treatments.

\begin{tabular}{lrccccc}
\hline Treatment & $\begin{array}{c}\text { Leukocyte } \\
\left(\mathrm{mm}^{3}\right)\end{array}$ & $\begin{array}{c}\text { Lymphocytes } \\
\left(10^{3} \mu \mathrm{L}^{-1}\right)\end{array}$ & $\begin{array}{c}\text { Neutrophils } \\
\left(10^{3} \mu \mathrm{L}^{-1}\right)\end{array}$ & $\begin{array}{c}\text { Monocytes } \\
\left(10^{3} \mu \mathrm{L}^{-1}\right)\end{array}$ & $\begin{array}{c}\text { Basophils } \\
\left(10^{3} \mu \mathrm{L}^{-1}\right)\end{array}$ & $\begin{array}{c}\text { Eosinophils } \\
\left(10^{3} \mu \mathrm{L}^{-1}\right)\end{array}$ \\
\hline Control & $110.2 \pm 20.5$ & $31.44 \pm 8.1$ & $16.3 \pm 4.92$ & $16.02 \pm 3.4$ & $0 \pm 0$ & $0.3 \pm 0.04$ \\
$1 \times 10^{6} \mathrm{UFC} \mathrm{g}^{-1}$ & $129.4 \pm 27.8$ & $26.31 \pm 13$ & $19.55 \pm 5.21$ & $15.03 \pm 4.7$ & $0 \pm 0$ & $0.31 \pm 0.2$ \\
$5 \times 10^{6} \mathrm{UFC} \mathrm{g}^{-1}$ & $105.92 \pm 14.3$ & $30.72 \pm 9.3$ & $16.2 \pm 4.16$ & $17.46 \pm 6.2$ & $0 \pm 0$ & $0.27 \pm 0.18$ \\
$1 \times 10^{7} \mathrm{UFC} \mathrm{g}^{-1}$ & $112 \pm 13.4$ & $28.11 \pm 6.4$ & $14.11 \pm 3.1$ & $14.6 \pm 7.2$ & $0 \pm 0$ & $0.32 \pm 0.23$ \\
\hline
\end{tabular}
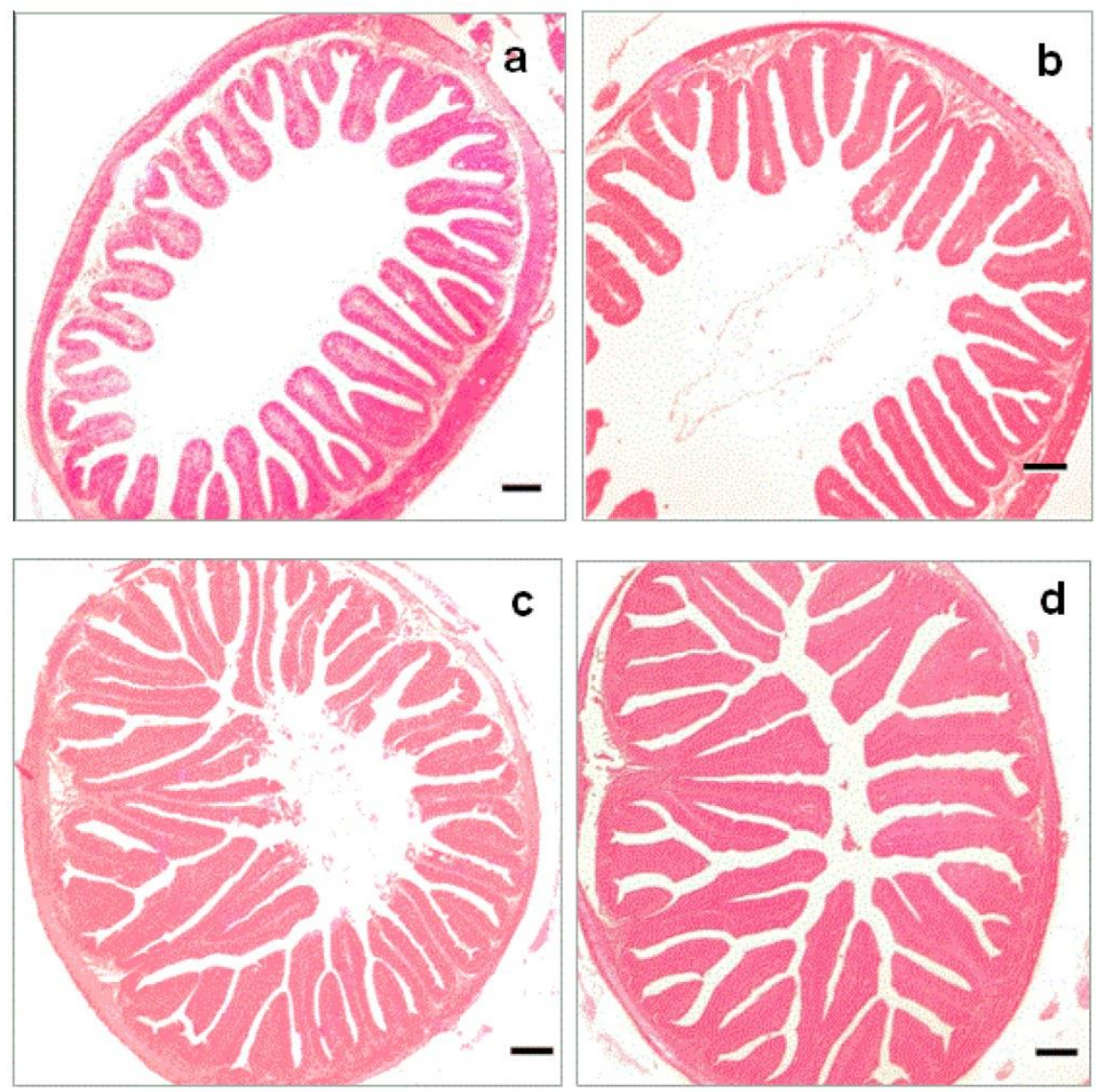

Figure 1. Comparative photomicrographs of the anterior portion of the intestine of Nile tilapia fed different probiotic concentrations in the diet. a) Control group, b) $1 \times 10^{6} \mathrm{CFU} \mathrm{g}^{-1}$, c) $5 \times 10^{6} \mathrm{CFU} \mathrm{g}^{-1}$, and d) $1 \times 10^{7} \mathrm{CFU} \mathrm{g}^{-1}$. Villi height enhanced proportionally to the concentration of the probiotic. Scale bar: $200 \mu \mathrm{m}$. Stain: hematoxylin-eosin. 


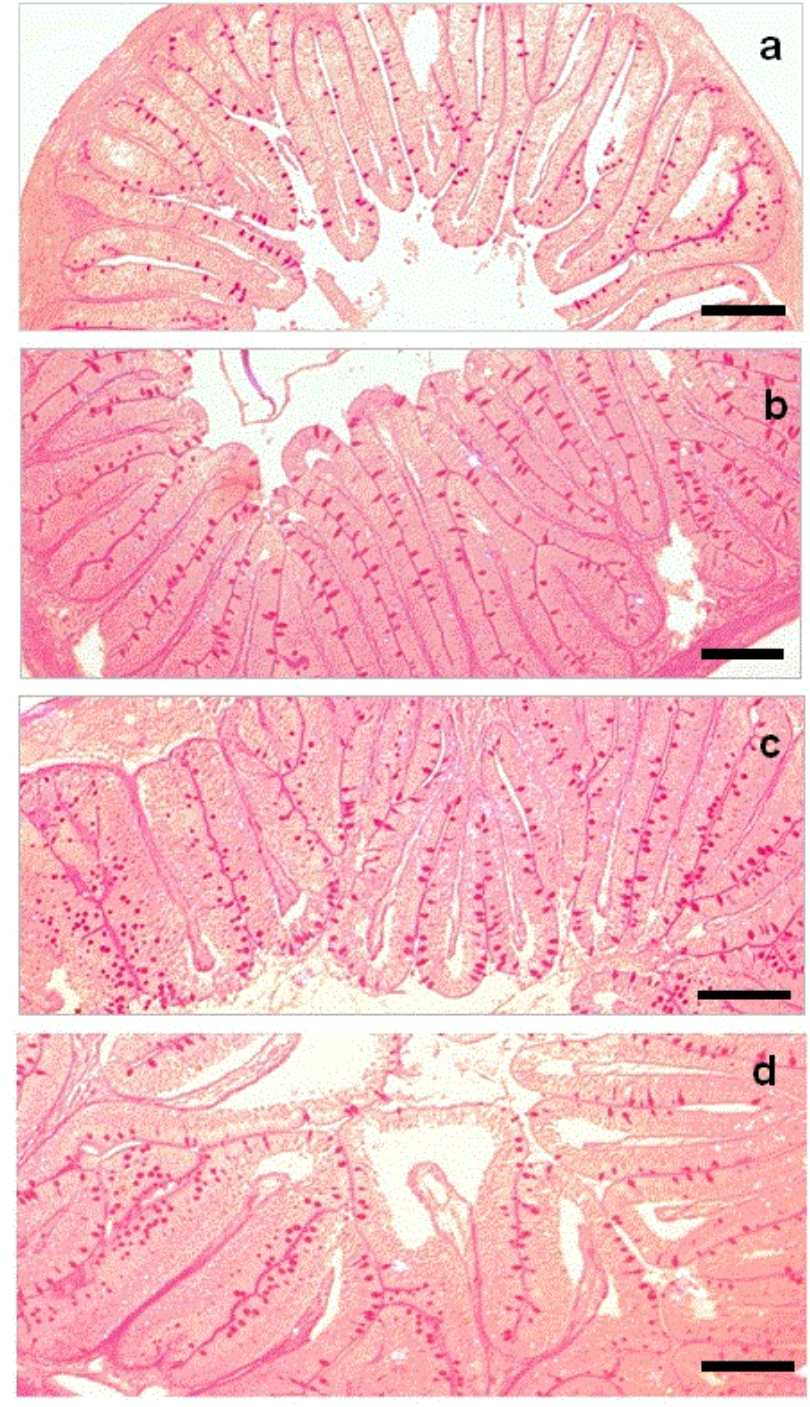

Figure 2. Comparative photomicrographs of the epithelial layer of the intestinal villi of Nile tilapia supplemented with different probiotic concentrations in the diet. a) Control group, b) $1 \times 10^{6} \mathrm{CFU} \mathrm{g^{-1 }}$, c) $5 \times 10^{6} \mathrm{CFU} \mathrm{g}^{-1}$, and d) $1 \times 10^{7} \mathrm{CFU} \mathrm{g}^{-1}$. Goblet cells (deep red colour -magentacells on the edge of the villi) increased proportionally to the concentration of the probiotic in the diet. Scale bar: $100 \mu \mathrm{m}$. Stain: Periodic acid-Schiff (PAS).

previously supplemented with the bacterium showed better growth performance than control group, suggesting that the effects of this probiotic occur over time. Unlike this report, in the present study fish were reared in cages in a reservoir with abundant algae (low transparency of water). This availability of food could influence the growth performance of fish, explaining why there was no difference between treatments.

The efficiency of nutrient transfer from food to the organism can be measured by the proximal composition analysis. This is of great importance due to it may reflect the nutritional value of the fish and its organoleptic characteristics (Contreras, 1994). Several authors have reported improvements in body composition of Nile tilapia supplemented with probiotics (Mello et al., 2013; Hassaan et al., 2014; Reda \& Selin, 2015). However, in this study, body composition analysis values showed no significant difference between treatment and control groups. Similar results were found by Telli et al., (2014) in Nile tilapia fed diet supplemented with $B$. subitilis.

Hematological variables are commonly used as indicators of physiological condition in fish (Mohapatra et al., 2014). Some studies reported that after feeding with Bacillus sp., Nile tilapia presented alterations on the hematological variables (Hassaan et al., 2014; Telli et al., 2014.) or not (Kumar et al., 2006; Soltan \& El-Laithy, 2008). In the present study, we did not observe differences in hematocrit, red blood cells count and hematological indices (MCHC, $\mathrm{MCH}$ and MCV). However, there was a higher hemoglobin levels in the fish fed with lower concentrations of probiotic. This could be related to the necessity of transport more oxygen in blood to meet the increasing energy demand of fish promoted by high levels of glucose (Nikinmaa et al., 1983).

As in current study, Reda \& Selim (2015) observed increase in hemoglobin levels in blood of Nile tilapia supplemented with B. amyloliquefaciens. However, the authors also observed an increase in the number of erythrocytes and leukocytes in blood, but without changes in blood glucose. They were reporter that probiotic bacteria enhance the iron absorption due to the release of organics acids in the gut. This would increase the availability of iron to produce hemoglobin in rats (Yadav et al., 2007) and fish (Dahiya et al., 2012).

Probiotics enhance fish tolerance to stress agents of environmental origin or related to handling (TapiaPaniagua et al., 2014). During stress, the release of catecholamines stimulates glycogenolysis (MartínezPorchas et al., 2009). The rapid increase of glucose in blood is one indicator of stress in fish (Simoes et al., 2012). In the present study, the higher blood glucose observed in the control group compared to supplemented ones with the greater inclusion of probiotic in the diet may reflect the homeostatic state of the animals against adverse conditions. B. amyloliquefaciens seems to have positively influenced the glucose levels of fish supplemented with $5 \times 10^{6} \mathrm{CFU} \mathrm{g}^{-1}$ and $1 \times 10^{7} \mathrm{CFU} \mathrm{g}^{-1}$ of feed, enhancing the homeostatic state of fish. Similar findings have been reported by Mohapatra et al. (2014) in Labeo rohita stressed that presented lower glucose levels in fish fed with this probiotic. 
Table 6. Histomorphometric parameters and goblet cells per villus in the intestine of Nile tilapia fed the experimental diets. Mean \pm SD. Values (mean \pm SD) with different letter are significantly different $(P<0.05)$.

\begin{tabular}{lccccc}
\hline Treatments & $\begin{array}{c}\text { Total height } \\
\text { of villi }(\mu \mathrm{m})\end{array}$ & $\begin{array}{c}\text { Height of villi } \\
(\mu \mathrm{m})\end{array}$ & $\begin{array}{c}\text { Width of } \\
\text { villi }(\mu \mathrm{m})\end{array}$ & $\begin{array}{c}\text { Epithelium } \\
\text { thickness }(\mu \mathrm{m})\end{array}$ & $\begin{array}{c}\text { Goblet cell } \\
\text { count per villi }\end{array}$ \\
\hline Control & $466.0 \pm 92.9^{\mathrm{a}}$ & $378.1 \pm 99.7^{\mathrm{b}}$ & $62.5 \pm 27.7^{\mathrm{a}}$ & $113.3 \pm 83.4^{\mathrm{a}}$ & $11.38 \pm 5.2^{\mathrm{b}}$ \\
$1 \times 10^{6} \mathrm{UFC} \mathrm{g}^{-1}$ & $407.2 \pm 121.1^{\mathrm{a}}$ & $371.3 \pm 91.6^{\mathrm{b}}$ & $51.4 \pm 8.7^{\mathrm{a}}$ & $98.9 \pm 19.8^{\mathrm{a}}$ & $16.45 \pm 6.63^{\mathrm{ab}}$ \\
$5 \times 10^{6} \mathrm{UFC} \mathrm{g}^{-1}$ & $438.4 \pm 105.5^{\mathrm{a}}$ & $423.2 \pm 95.3^{\mathrm{a}}$ & $54.2 \pm 11.4^{\mathrm{a}}$ & $118.3 \pm 21.5^{\mathrm{a}}$ & $25.24 \pm 8.32^{\mathrm{a}}$ \\
$1 \times 10^{7} \mathrm{UFC} \mathrm{g}^{-1}$ & $487.2 \pm 31.2^{\mathrm{a}}$ & $469.4 \pm 25.1^{\mathrm{a}}$ & $57.0 \pm 13.3^{\mathrm{a}}$ & $107.3 \pm 23.9^{\mathrm{a}}$ & $23.32 \pm 8.43^{\mathrm{a}}$ \\
\hline
\end{tabular}

Stress is one of the factors that contribute to the emergence of primary diseases and mortality of reared fish. Both food and environmental changes could promote stress modifying the gut microbiota and the establishment of pathogens in the gastrointestinal tract (Tannock \& Savage, 1974). Thus, it is likely that an improvement in the homeostatic level promoted by the probiotic in this study may be related to increased stability of the gut microbiota with reduction of harmful bacteria in the epithelium (Rollo et al., 2006).

The intestinal lumen of the fish is lined by a simple columnar epithelium interspersed with goblet cells (Reifel \& Travill, 1979). The integrity of the intestinal mucosa is a consequence of the intensity of epithelial cell renewal that determines the uniformity of the villi and the number of goblet cells (Mello et al., 2013).

The increased villi height observed in the supplemented groups in this study and the lower number of pathogenic bacteria in the enterocytes could be related to the increased availability of nutrients and reduced desquamation of the epithelium. Furthermore, it is known that some proteins produced by probiotic bacteria promote increased cellular survival time of the intestinal tract due to the inhibition of apoptosis signaling induced by cytokines (Sherman et al., 2009).

Mello et al. (2013) observed in Nile tilapia fed diets containing Bacillus cereus and B. subtilis an increasing of the area of absorption, nutrient retention and consequent improvement in growth performance and body composition. In this study, although the intestinal absorption area has grown substantially, there was no difference in performance. This can be explained due to the short evaluation time, which was not enough to show its effects in performance and proximal analysis. It can also relate to the low concentration of the probiotic or due to the adverse weather conditions recorded in the last month of the experiment in which the temperature decreased.

The production of mucus by goblet cells is an important mechanism of protection against the entry of pathogens through the intestinal tract (Ellis, 2001). Furthermore, the mucus has bactericidal effect, protects against toxic substances and aids the transport between the luminal contents and epithelial cells (Smirnov et al., 2005).

It is well documented that probiotics stimulate the development of goblet cells in the intestine (Nayak, 2010; Mello et al., 2013). In this study, fish that received the highest level of inclusion of probiotic showed significantly higher number of goblet cells compared to control group. This result corroborates the observations of Reda \& Selim (2015) that observed growth of the villi and increased goblet cell number in fish supplemented with B. amyloliquefaciens.

From the results obtained, it is possible to suggest that in the tested conditions, the use of B. amyloliquefaciens in the diet presented good indications, increasing the size of the intestinal villi, number of goblet cells and enhancing the homeostatic state of the fish. However, it is necessary longer studies with larger concentrations of the probiotic in field conditions to asseverate that the use of this product is suitable to Nile tilapia.

\section{ACKNOWLEDGEMENTS}

We would like to thank FAPESP (2012/10090-4) for financing this study.

\section{REFERENCES}

Association of Official Analytical Chemists (AOAC). 2000. Official methods of analysis of the Association of Official Analytical Chemists. AOAC, Arlington, $1234 \mathrm{pp}$.

Ayandiran, T.A., A.A. Ayandele, S.O. Dahunsi \& O.O. Ajala. 2014. Microbial assessment and prevalence of antibiotic resistance in polluted Oluwa River, Nigeria. Egypt. J. Aquat. Res., 40, 3: 291-299.

Boyd, C. \& L. Massaut. 1999. Risks associated with the use of chemicals in pond aquaculture. Aquacult. Eng., 20: 113-132. 
Cao, H., S. He, R. Wei, M. Diong \& L. Lu. 2011. Bacillus amyloliquefaciens $\mathrm{G1}$ : a potential antagonistic bacterium against eel-pathogenic Aeromonas hydrophila. Evidence-based complement. Altern. Med., pp. 1-7.

Chi, C., B. Jiang, X.-B. Yu, T.-Q, Liu, L, Xia \& G.-X Wang. 2014. Effects of three strains of intestinal autochthonous bacteria and their extracellular products on the immune response and disease resistance of common carp, Cyprinus carpio. Fish. Shellfish Immunol., 36: 9-18.

Collier, H.B. 1944. Standardization of blood haemoglobin determinations. Can. Med. Assoc. J., 50: 550-552.

Contreras, G.E.S. 1994. Bioquímica de pescados e derivados. Funep, Jaboticabal, 409 pp.

Dahiya, T., R.C. Sihag \& S.K. Gahlawat, 2012. Effect of Probiotics on the Haematological Parameters of Indian Magur (Clarius batrachus L.). J. Fish Aquat. Sci., 7: 279-290.

Das, A., K, Nakhro, S. Chowdhury \& D, Kamilya. 2013. Effects of potential probiotic Bacillus amyloliquifaciens FPTB16 on systemic and cutaneous mucosal immune responses and disease resistance of catla (Catla catla). Fish Shellfish Immunol., 35: 1547-1553.

Ellis, A.E. 2001. Innate host defense mechanisms of fish against viruses and bacteria. Dev. Comp. Immunol., 25: 827-839.

Furuya, W. 2010. Tabelas brasileiras para a nutrição de tilápias. Grafica \& Editora, Toledo, 100 pp.

Garcia, F., J.M. Kimpara, W.C. Valenti \& L.A Ambrosio. 2014. Emergy assessment of tilapia cage farming in a hydroelectric reservoir. Ecol. Eng., 68: 72-79.

Goldenfarb, P.B., F.P. Bowyer, E. Hall \& E. Brosious. 1971. Reproducibility in the hematology laboratory: the microhematocrit determination. Am. J. Clin. Pathol., 56: 35-39.

Han, Y., E. Liu, L. Liu, B. Zhang, Y. Wang, M. Gui, R. Wu \& P. Li. 2015. Rheological, emulsifying and thermostability properties of two exopolysaccharides produced by Bacillus amyloliquefaciens LPL061. Carbohyd. Polym., 115: 230-237.

Hassaan, M.S., M.A. Soltan \& M.M.R. Ghonemy. 2014. Effect of synbiotics between Bacillus licheniformis and yeast extract on growth, hematological and biochemical indices of the Nile tilapia (Oreochromis niloticus). Egypt. J. Aquat. Res., 40: 199-208.

Honorato, C.A., C.D. Cruz, D.J. Carneiro \& M.R.F. Machado. 2011. Histología e histoquímica do intestino anterior de tilápia do Nilo (Oreochromis niloticus) alimentadas com dietas contendo silagem de peixe. Braz. J. Vet. Res. Anim. Sci., 48: 4 pp.

Kaewklom, S., S. Lumlert, W. Kraikul \& R. Aunpad. 2013. Control of Listeria monocytogenes on sliced bologna sausage using a novel bacteriocin, amysin, produced by B. amyloliquefaciens isolated from Thai shrimp paste (Kapi). Food Control, 32: 552-557.

Kersarcodi-Watson, A., H. Kaspar, M.J. Lategan \& L. Gibson. 2008. Probiotics in aquaculture: the need, principles and mechanisms of action and screening processes. Aquaculture, 274: 1-14.

Kim, T., J. Lee, D.W. Fredriksson, J. DeCew, A. Drach \& K. Moon. 2014. Engineering analysis of a submersible abalone aquaculture cage system for deployment in exposed marine environments. Aquacult. Eng., 63: 72-88.

Kumar, R., S.C. Mukherjee, K.P. Prasad \& A.K. Pal. 2006. Evaluation of Bacillus subtilis as a probiotic to Indian major carp Labeo rohita (Ham.). Aquacult. Res., 37: 1215-1221.

Lee, J., S. Rheem, B. Yun, Y. Ahn, J. Joung, S.J. Lee, S. Oh, T. Chun, I. Rheem, H.S. Yea, K.S. Lim, J.M. Cha \& S. Kim. 2013. Effects of probiotic yoghurt on symptoms and intestinal microbiota in patients with irritable bowel syndrome. Int. J. Dairy Technol., 66: 243-255.

Loncar, N., N. Gligorijević, N.A. Božić \& Z. Vujčić. 2014. Congo red degrading laccases from Bacillus amyloliquefaciens strains isolated from salt spring in Serbia. Int. Biodeter. Biodegr., 91: 18-23.

Mahdhi, A., M. Esteban, Z. Hmila, K. Bekir, F. Kamoun, A. Bakhrouf \& B. Krifi. 2012. Survival and retention of the probiotic properties of Bacillus sp. strains under marine stress starvation conditions and their potential use as a probiotic in Artemia culture. Res. Vet. Sci., 93: 1151-1159.

Marcusso P., J. Yunis, G. Claudiano, S. Eto, D. Fernandes, H. Mello, F. Marinho Neto, R. Salvador, J.R. Moraes \& F.R. Moraes. 2015. Influence of temperature on Streptococcus agalactiae infection in Nile tilapia. Braz. J. Vet. Res. Anim. Sci., (52)1: 57-62.

Martinez-Porchas, M., L.R. Martinez-Cordova \& R. Ramos-Enriquez. 2009. Cortisol and glucose: reliable indicators of stress? Pan-Am. J. Aquat. Sci., 4: 158178.

Mello, H.D., J.R.E. Moraes, I.G. Niza, F.R.D. Moraes, R.O.A. Ozório, M.T. Shimada, J.R. Engracia Filho \& G.S. Claudiano. 2013. Efeitos benéficos de probióticos no intestino de juvenis de Tilápia-do-Nilo. Pesq. Vet. Brasil., 33: 724-730.

Mohapatra, S., T. Chakraborty, A. Prusty, K. PaniPrasad \& K. Mohanta. 2014. Beneficial effects of dietary probiotics mixture on hemato-immunology and cell apoptosis of Labeo rohita fingerlings reared at higher water temperatures. PLoS ONE, 9(6): 1-9.

Nayak, S. 2010. Probiotics and immunity: a fish perspective. Fish Shellfish Immunol., 29: 2-14. 
Nikinmaa, M., A. Soivio, T. Nakari \& S. Lindgren. 1983. Hauling stress in brown trout (Salmo-trutta): physiological responses to transport in fresh-water or salt-water, and recovery in natural brackish water. Aquaculture, 34: 93-99.

Priest, F., M. Goodfellow, L. Shute \& R. Berkeley. 1987. Bacillus amyloliquefaciens sp. nov., nom rev. Int. J. Syst. Bacteriol., 37: 69-71.

Ran, C., A. Carrias, M. Williams, N. Capps, B. Dan, J. Newton, J. Kloepper, E. Ooi, C. Browdy, J. Terhune \& M. Liles. 2012. Identification of Bacillus strains for biological control of catfish pathogens. PLoS ONE, 7(9): 1-8.

Reda, R. \& K. Selim. 2015. Evaluation of Bacillus amyloliquefaciens on the growth performance, intestinal morphology, hematology and body composition of Nile tilapia, Oreochromis niloticus. Aquacult. Int., 23: 203-217.

Reifel, C.W. \& A.A. Travill. 1979. Structure and carbohydrate histochemistry of the intestine in ten teleostean species. J. Morphol., 162: 343-359.

Ridha, M. \& I. Azad. 2012. Preliminary evaluation of growth performance and immune response of Nile tilapia Oreochromis niloticus supplemented with two putative probiotic bacteria. Aquacult. Res., 43: 843852.

Rollo, A., R. Sulpizio, M. Nardi, S. Silvi, C. Orpianesi, M. Caggiano, A. Cresci \& O. Carnevali. 2006. Live microbial feed supplement in aquaculture for improvement of stress tolerance. Fish. Physiol. Biochem., 32: 167-177.

Sanger, F., S. Nicklen \& A. Coulson. 1977. DNA sequencing with chain-terminating inhibitors. P. Natl. Acad. Sci. Usa., 74: 5463-5467.

Sherman, P., J. Ossa \& K. Johnson-Henry. 2009. Unraveling mechanisms of action of probiotics. Nutr. Clin. Pract., 24: 10-14.

Simões, L.N., A.T.M. Gomide, V.M.F. Almeida-Val, A.L Val \& L.C Gomes. 2012. O uso do óleo de cravo como anestésico em juvenis avançados de tilápia do Nilo (Oreochromis niloticus). Acta Sci. Anim. Sci., 34: 175-181.

Smirnov, A., R. Perez, E. Amit-Romach, D. Sklan \& Z. Uni. 2005. Mucin dynamics and microbial populations in chicken small intestine are changed by dietary probiotic and antibiotic growth promoter supplementation. J. Nutr., 135: 187-192.

Received: 28 July 2015; Accepted: 25 September 2015
Soltan, M.A. \& S.M.M. El-Laithy. 2008. Effect of probiotics and some spices as feed additives on the performance and behaviour of Nile tilapia, Oreochromis niloticus. Egypt. J. Aquat. Biol. Fish., 12(2): 63-80.

Tannock, G. \& D. Savage. 1974. Influences of dietary and environmental stress on microbial populations in murine gastrointestinal-tract. Infect. Immunol., 9: 591598.

Tapia-Paniagua, S.T., S. Vidal, C. Lobo, M.J. PrietoÁlamo, J. Jurado, H. Cordero, R. Cerezuela, I. García de la Banda, M.A. Esteban, M.C. Balebona \& M.A. Moriñigo. 2014. The treatment with the probiotic Shewanella putrefaciens Pdp11 of specimens of Solea senegalensis exposed to high stocking densities to enhance their resistance to disease. Fish Shellfish Immunol., 41: 209-221.

Telli, G., M. Ranzani-Paiva, D. Dias, F. Sussel, C. Ishikawa \& L. Tachibana. 2014. Dietary administration of Bacillus subtilis on hematology and nonspecific immunity of Nile tilapia Oreochromis niloticus raised at different stocking densities. Fish Shellfish Immunol., 39: 305-311.

Wang, L., F. Lee, C. Tai \& H. Kuo. 2008. Bacillus velezensis is a later heterotypic synonym of Bacillus amyloliquefaciens. Int. J. Syst. Evol. Microbiol. 58: 671-675.

Wedemeyer, G. 1970. Stress of anesthesia with ms-222 and benzocaine in rainbow trout (Salmo gairdneri). J. Fish. Res. Bd. Can., 27: 909 pp.

Wu, H-J., L-B. Sun, C-B. Li, Z-Z. Li, Z. Zhang, X-B. Wen, Z. Hu, Y-L. Zhang \& S-K. Li. 2014. Enhancement of the immune response and protection against Vibrio parahaemolyticus by indigenous probiotic Bacillus strains in mud crab (Scylla paramamosain). Fish Shellfish Immunol., 41: 156162.

Yadav H., J. Shalini \& P.R. Sinha. 2007. Antidiabetic effect of probiotic dahi containing Lactobacillus acidophilus and Lactobacillus casei in high fructose fed rats. Nutrition, 23: 62-68.

Ziaei-Nejad, S., M. Rezaei, G. Takami, D. Lovett, A. Mirvaghefi \& M. Shakouri. 2006. The effect of Bacillus spp. bacteria used as probiotics on digestive enzyme activity, survival and growth in the Indian white shrimp Fenneropenaeus indicus. Aquaculture, 252: 516-524. 